\title{
EM BRIGA DE MARIDO E MULHER SE METE A COLHER: A LeI MARIA da Penha à luz da teoria da DEMOCRACIA DE HABERMAS ${ }^{1}$
}

\section{Aline Magna Cardoso Barroso Lima²}

\begin{abstract}
Resumo
As reflexões deste artigo concentram-se na análise das políticas afirmativas do Estado no combate à violência conjugal, em especial a Lei Maria da Penha, à luz da teoria da democracia de Habermas. Pondera-se sobre a efetividade de suas disposições no equacionamento das questões de gênero levantadas pelo movimento feminista, na década de 70, e apropriada pelo Estado como um programa político a ser cumprido e expropriada da racionalidade comunicativa dos indivíduos integrantes da sociedade civil.

Palavras-chave: Feminismo. Habermas. Estado. Lei Maria da Penha.
\end{abstract}

\begin{abstract}
s
This article reflects on the analysis of the affirmative politics of the State in combating conjugal violence, in particular the Maria da Penha Law, in light of Habermas's theory of democracy. We ponder the effectiveness of its measures in addressing the

\footnotetext{
${ }^{1}$ Agradeço às imprescindíveis orientações dos mestres-amigos Dr. José Rodorval Ramalho e Dra. Monica Santana, que despertaram em mim a curiosidade sociológica.

${ }^{2}$ Aluna regular do Mestrado em Sociologia da Universidade Federal de Sergipe. Pós-graduada em Direito Processual Constitucional e graduada em Direito também pela Universidade Federal de Sergipe. Endereço eletrônico alinemagna@yahoo.com.br
} 
gender issues raised by the feminist movement of the 1970s, appropriated by the State as a political program and expropriated of the communicative rationality of the individuals who are members of civil society.

Keywords: Feminism. Habermas. State. Maria da Penha Law.

\section{INTRODUÇÃO}

$\mathrm{P}$ arafraseando Miriam Grossi (1998), pretendo deixar claro que sou adepta dos princípios humanitários e considero a violência, em qualquer forma de manifestação, um mal que deve ser combatido, denunciado e eliminado de todas as relações sociais, como forma do pleno exercício da cidadania. Refletir sobre aspectos não consensuais ou não tradicionais da problemática da violência contra a mulher pode ser uma faca-de-dois-gumes, quais sejam: consistir numa contribuição para os que estão em busca de mecanismos de transformação social, ou poderá tornar-se, nas mãos de orador habilidoso, um poderoso instrumento à serviço da manutenção de determinadas situações. Assim, todos que se arvoram por estas veredas expõem-se ao duro olhar de militantes feministas e até mesmo dos que reverenciam as tradições acadêmicas. Entretanto, arrisco-me ao apresentar um olhar diferenciado sobre o tema.

0 levantamento dos índices da violência contra a mulher no Brasil - tanto nos institutos de pesquisa oficiais, quanto em trabalhos acadêmicos, notícias, em exposição de motivos de leis e projetos de leis que visam o seu combate - denotam a gravidade do problema e o surgimento de novas formas de violência no espaço doméstico. Paralelamente a isto, pesquisas qualitativas que buscam seus dados a partir de entrevistas com os atores do fato social, em especial as mulheres vitimadas pela violência (a exemplo dos trabalhos de Gregori (1992), Machado (1998), Grossi (1998) citados) parecem mostrar que há um impasse nas políticas públicas afirmativas propostas até hoje, no Brasil, para a solução deste grave problema social, pois um número significativo de mulheres vítima de violência em seu cotidiano doméstico, apesar de terem do Estado delegacias especializadas para seu atendimento, legalização do divórcio, assistência judiciária gratuita, e, do discurso feminista e do senso comum total apoio em sua cruzada contra a violência masculina, não conseguem sair desta situação de extremo e, muitas vezes, absurdo, sofrimento. 
Há explicações universais para o fenômeno: dependência econômica, mercado de trabalho restrito e desigual para as mulheres, número excessivo de filhos, a onipresente e perene dominação masculina. Contudo, elas parecem cada vez mais distantes à medida que o processo de libertação feminina acontece. A expansão do círculo moral, os progressos tecnológicos e econômicos que possibilitou o planejamento do número de filhos, que otimizou as tarefas domésticas não exigindo mais o confinamento feminino para cuidar da prole, o acesso à educação e ao mercado de trabalho que se deve em grande parte ao feminismo (movimento político, acadêmico, literário que canalizou estes avanços para mudanças tangíveis na sociedade) tornam tais explicações generalistas insuficientes para abranger a totalidade do fenômeno.

Todavia, é, por vezes, com base nas explicações generalizantes que 0 Estado elabora suas ações e, princípios como a igualdade (próprios do Estado de Direito) tornam-se incompatíveis com as medidas eleitas. Como afirmou Pinker (2002), igualdade não é a afirmação empírica de que todos os grupos humanos são intercambiáveis; é o princípio moral de que os indivíduos não devem ser julgados nem refreados com base nos atributos médios de seu grupo. No tocante à questão de gênero, no Brasil, a Constituição Federal de 1988 determina clara e sucintamente que: "Todos são iguais perante a lei, sem distinção de qualquer natureza..."; reconhecendo a igualdade, desnecessárias são explicações sobre a indistinguibilidade dos sexos para justificá-la. Ao revés, também não seria admitido invocar diferenças entre os sexos para justificar políticas discriminatórias ou para fazer sermão às mulheres sobre o que elas não querem fazer. Nenhuma diferença entre os sexos aplica-se a todos os homens em comparação com todas as mulheres indistintamente. 0 que sabemos sobre eles também não requer nenhuma ação que penalize ou reprima um sexo ou outro de forma geral e absoluta.

Com base nestas considerações, elaboramos esta reflexão. Contribuir para o debate acerca dos motivos que levam as mulheres a se manterem em relações violentas, à guisa de haver proteção específica do Estado, atualmente, representada pela Lei 11.340/2006 que "cria mecanismos para coibir a violência doméstica e familiar contra a mulher”, e sobre sua potencial eficácia.

Neste caminho, iniciamos com a apresentação dos conceitos e categorias que foram sendo construídos e apropriados pelos envolvidos no fato social destacado, reflexivamente, e que representam uma instância de disputa política pela visibilidade e legitimidade das questões que envolvem o masculino e 0 feminino. Como ponto central do capítulo o tema da vitimização feminina: 
a crítica acadêmica sobre os discursos generalizantes e a sua apropriação pela sociedade e pelas instituições públicas, em especial o Poder Judiciário e as leis protetivas do Estado. Apresentamos as nuanças da Lei 11.340/2006, criada com o objetivo de coibir a violência no âmbito doméstico e familiar, utilizandose de categorias generalistas e das diferenças dos sexos para justificar políticas discriminatórias e atentatórias ao princípio da igualdade ao tratar a mulher como vítima independente de seu perfil social e do caráter da violência sofrida e o homem como agressor, qualquer que seja a situação, num diálogo com a teoria de democracia de Habermas. Como o autor nos apresenta, em sua teoria, uma situação idealizada da relação entre as instituições e a sociedade civil, o referencial serve como termômetro para verificar o nível de limitação das práticas institucionais feministas que pretendem solucionar tão complexa e subjetiva relação com a objetividade de uma lei que desconsidera que há diferenças entre as mulheres e que elas têm um poder de agenciamento, mesmo em contexto muito machistas, como afirma Debert (2006).

\section{O FEMINISMO EM REFLEXÃO: ENCONTROS E DESENCONTROS COM A ACADEMIA}

Em 1990, a produção científica brasileira sobre as temáticas mulher passou por um momento de reflexão dentro do seminário realizado pela Fundação Carlos Chagas com o apoio da Fundação Ford intitulado "Estudos sobre Mulher no Brasil: Avaliação e Perspectivas". 0 balanço tinha como objetivo avaliar os avanços teóricos e metodológicos, bem como as lacunas do campo temático mulher/gênero. A necessidade desta avaliação devia-se ao acelerado processo de expansão da área, que desde 1970 havia emergido da invisibilidade sob o impacto da mobilização feminista. (COSTA e BRUSCHINI, 1992).

0 vínculo estabelecido entre o movimento feminista brasileiro (a partir de 1970) e as pesquisas realizadas pela comunidade científica brasileira redundou, num primeiro momento, em estudos fortemente permeados pelo olhar crítico feminista. A militância, que num primeiro momento havia despertado o interesse pelos estudos sobre mulheres, acaba por contaminar a neutralidade científica, daí a importância das reflexões trazidas pelo seminário, no sentido de apontar outras análises possíveis, outros campos inexplorados na área, além de revigorar os interesses pelo estudo. 0 seminário também é um marco na passagem dos estudos de mulher para os de gênero. A noção de gênero aponta para o caráter 
implicitamente relacional do masculino e do feminino e, ainda, está ligado à idéia de diferença e de desconstrução.

A introdução de gênero como categoria de análise pela academia acabou por desestruturar ou reestruturar os paradigmas do feminismo clássico, instaurando um questionamento cruzado na relação entre o feminismo e a produção acadêmica: o dever de afirmar as diferenças construídas socialmente como femininas, na qualidade de alternativas possíveis de uma universalidade; ou o dever de processar infinitamente a desconstrução e duvidar inclusive das novas formas que vêm sendo construídas para o feminino. A partir disto, os encontros e desencontros entre feministas e academias não se reduzem mais em saber das relações insterinstitucionais ou se as acadêmicas são ou foram militantes, mas em descobrir se tais divergências não são produtos da auto-reflexão que faz a chamada cultura ocidental na passagem para a pós-modernidade. (MACHADO apud COSTA e BRUSCHINI, 1992)

Feminismo e academia se encontram em ebulição, num momento de questionamento de seus próprios paradigmas, o que torna a sua relação mais complexa. 0 feminismo de posição unitária perdeu a sua visibilidade, pois, as falas clássicas que outrora congregavam militantes assíduas, hoje, não surtem mais tanto efeito. Os novos rumos da discussão levam a uma autocrítica de seus próprios mitos. 0 momento não é de respostas, mas sim de questionamentos.

E é neste momento reflexivo do feminismo e da pesquisa científica acadêmica que fazemos algumas observações sobre as políticas para erradicação de 'todo o tipo' de discriminação contra a mulher na sociedade brasileira pretendida pela edição da Lei Maria da Penha, a partir da análise da categoria "violência contra a mulher", a fim de observar em que medida este processo de autocrítica das relações entre feminismo e academia reverberou na mudança das medidas afirmativas adotadas pelo Estado para atender as demandas políticas da questão feminina e se, também, influenciou na forma como as mulheres elaboram seus papéis sociais hoje.

Apesar do reconhecimento de inúmeras formas de violência contra as mulheres passíveis de denúncia, a grande maioria das queixas registradas nas instituições se refere à violência doméstica, ou seja, agressões sofridas no âmbito do casamento (ou de relações afetivas com a mesma carga emocional e/ou social), o que faz com que, no Brasil, "violência contra a mulher" seja utilizada como sinônimo de "violência doméstica" (GROSSI apud PEDRO e GROSSI, 1998). 
Neste contexto de violência, a adoção política, pelas instituições públicas, do programa que funda o feminismo vitimista, (que aposta menos numa teoria da relação entre os sexos e se apresenta mais como um ato de acusação contra o outro sexo e contra um sistema de opressão) parece estar em descompasso com as atuais reflexões em que se enredaram academia e movimento feminista, que buscam novas prospecções sobre o tema, não a partir da condição da mulher somente, mas sob a perspectiva relacional introduzida pela idéia de gênero. Seria hora de nos perguntarmos se esta escolha produziu uma representação da mulher que nos ameaça retroceder muitos passos ao invés de nos levarmos onde queremos ir.

Segundo Sorj (apud COSTA e BRUSCHINI, 1992), nas últimas décadas surgiram para as ciências sociais um conjunto de estudos feministas que produziram uma considerável reavaliação das explicações correntes da vida social, arrimadas nas experiências femininas e na crítica às teorias sociais (no que pertine a sua omissão na utilização das relações de gênero para a explicação da organização social).

Em 1985, no artigo "Participando do debate sobre a mulher e a violência", Marilena Chauí constrói a idéia de que a violência contra a mulher é resultado de "um processo de produção e reprodução de uma ideologia de dominação masculina, difundida através de um discurso construído pelos homens sobre o mundo social e sobre as mulheres e seus respectivos papéis". (CHAUÍ apud ROMEIR0, 2006, p. 40). Para a autora, as desigualdades se estruturam hierarquicamente, como resultado das diferenças entre homens e mulheres, através dos discursos masculinos que organizam a vida social.

A mulher, para Chaú, passa a ser entendida como um corpo, um anexo do masculino; e este discurso construído sobre as mulheres e não pelas mulheres encontra condição de possibilidade no seu silêncio. Neste contexto, violência é a ação que transforma diferença em desigualdade com o fim de dominar, explorar e oprimir as mulheres. Esta subjetividade feminina, construída de forma dependente e inclinada a adotar a visão dominante masculina sobre o mundo social, transformaria as mulheres em vítimas, cúmplices e perpetradoras da violência que sofrem:

Durante a década de 1980, quando se desenvolveu esta teoria sobre violência conjugal, pesquisas foram desenvolvidas pelos Conselhos da Condição Feminina e pelo centro de Defesa dos Direitos da Mulher, incorporando esta noção de dominação masculina de Chauí que entende a "violência contra a 
mulher" como fruto de um processo de subordinação, o que tornaria as mulheres vítimas dos homens. 0 amalgamento político do discurso clássico do feminismo tomava forma nas instituições de defesa dos direitos da mulher. Segundo Gregori (1993), os autores que se valem das conceituações filosóficas de Chauí sobre violência contra as mulheres, abandonam a interessante análise que ela faz sobre a violência praticada entre mulheres e sobre as dificuldades que elas têm em se solidarizarem. Daí a sua opinião de que tais pesquisas têm um caráter de militância prevalente sobre o seu caráter científico, pois faltam-lhes neutralidade pra denunciar o problema e formular soluções concretas para solucioná-los. Os artigos adotam a conceituação de violência como forma de subordinação, e de forma conceitualmente genérica passam a reclamar punibilidade.

É também desta década o trabalho de Maria Amélia Azevedo, Mulheres espancadas: a violência denunciada (1985), denunciando a violência nesta mesma linha, contudo considerando-a como um fenômeno de 'múltiplas determinações', contrapondo-se ao argumento de violência estrutural do sistema capitalista, da exploração dos sexos. 0 objetivo da pesquisa era entender por que ocorrem as manifestações de força física, dentro das relações, dos homens contra as mulheres e por que nem todas as mulheres sofrem agressões por parte de seus parceiros, já que há a idéia generalizante de que os homens pretendem dominar as mulheres, tolhendo a sua liberdade, através da violência. Gregori (1993), também analisando a obra de Azevedo pondera sobre o tom denuncista da interpretação dos dados e na determinação da autora em demonstrar que, apesar das "múltiplas determinações", há uma pré-disposição do homem para bater em sua esposa - esta vontade explícita, ou desejo latente espera somente o pretexto (múltiplas determinações) para se manifestar. Assim, a violência seria a expressão de um conflito de interesses entre os sexos, baseada na disposição do homem em machucar a mulher, apoiado no processo global de dominação. Como Chauí, há uma criação de um ator coletivo e uma construção da posição das mulheres numa sociedade patriarcal. A falta de distanciamento do objeto levou Azevedo a elaborar uma base para o discurso feminista sem, contudo, conseguir responder a sua questão inicial: por que há mulheres que não sofrem violência de seus parceiros?

A necessidade de denunciar e formular soluções para o problema da violência somou-se à falta de neutralidade dos discursos feministas para reclamar a punibilidade desejada para os casos de violência. A academia acaba por se confundir com a militância, e todos os estudos denotam este caráter denuncista permeados de explicações gerais sobre a condição da mulher na sociedade. 
A filosofia do vitimismo na qual mesmo as mulheres que não são vítimas da violência, são também vítimas à medida que sujeitas a um processo global de desconstituição de sua identidade, encontra nestes trabalhos os seus referenciais teóricos.

Outra corrente teórica que orientou os trabalhos sobre violência no Brasil, também na década de 80, foi a perspectiva feminista e marxista do patriarcado ${ }^{3}$ desenvolvida por Heleieth Saffioti. A teoria sobre as relações de gênero de Saffioti (apud IZUMINO, 2004) estabelece-o contido num conjunto de relações sociais com uma base material e com relações hierárquicas solidária entre homens e mulheres, habilitando-os a controlar as mulheres. A idéia é que os homens criaram para si um sistema de organização social que assegura os meios de produção e reprodução, determinando a exclusão das mulheres, que seriam vistas como objeto de satisfação sexual e mera força de trabalho, obrigadas a seguir o regime imposto por eles.

A dualidade dominação/opressão dos campos político e ideológico também invade a esfera econômica e socializa homens e mulheres de acordo com a lógica machista de poder, mas dentro de uma totalidade dialética, na qual partes distintas interagem de forma orgânica.A violência, neste contexto, é uma das formas de manutenção deste poder (SAFFIOTI apud IZUMINO, 2004), à medida que, a formação do "macho" faz os homens julgarem-se no direito de espancar suas mulheres, enquanto estas, educadas para realizar os desejos masculinos, encaram a violência como natural. Não se trata de um movimento natural das relações de gênero, mas de uma naturalização das categorias, entendidas dentro de um espaço-temporal definido.

'Naturalização' de Saffioti e 'cumplicidade' de Chauí tem o mesmo significado: idéia de que a mulher organiza sua subjetividade a partir de uma perspectiva masculina; assim reproduzem e reforçam a desigualdade criada pelo patriarcado para as relações sociais e interpessoais, tendo em vista os diferentes lugares reservados para homens e mulheres neste sistema ideológico. A apropriação deste discurso acadêmico, pelos movimentos sociais, se dá pela adoção da idéia de "dominação masculina" de Chauí combinada com a noção de "vitimização" da

\footnotetext{
${ }^{3} 0$ termo patriarcado, para Saffioti (1992), poderia ser pensado como um dos esquemas de dominação-exploração componentes de uma simbiose da qual participam também o modo de produção e o racismo. Para a autora, visto desta forma, ele pode ser utilizado para designar outra concepção das relações de gênero (simbiose patriarcado-racismo-capitalismo), diferente das resultantes das posturas dualistas como a de Weber, por exemplo.
} 
mulher nas relações desiguais de poder, no sistema de opressão/dominação de Saffioti (IZUMINO, 2004).

A idéia de "cumplicidade" da violência não seria condizente com a necessidade de dar visibilidade aos casos de "violência contra a mulher" e com a importância de se criar uma justificativa que sensibilizasse ao tempo em que conferisse relevância à questão, ante o Estado e aos organismos financiadores do movimento de legitimação da causa feminista, por isto esta idéia foi subsumida no aporte do clássico vitimismo, somente.

Desvelar ao espaço público relações entendidas e resolvidas na intimidade das conexões pessoais implicaria não evidenciar as implicações da "vitimização" da mulher. Assim, constrói-se as categorias políticas "violência doméstica" e "familiar" com o fim específico de evidenciar um tipo característico de violência praticado por homens contra 'suas' mulheres, no universo íntimo do casal. Os termos incorporaram a noção da condição de "não sujeito" da mulher nas relações e ressaltam suas fragilidades frente aos consortes. Desde 1980, então, as pesquisas acadêmicas sobre "violência conjugal contra a mulher" tinham este caráter de denúncia e militância (IZUMINO, 2004).

Em virtude da não problematização do uso destas categorias (violência contra a mulher, violência doméstica e violência familiar) incorporou-se a idéia de que "violência contra a mulher" é um tipo específico de violência praticada pelos homens contra as mulheres, com as quais guardam vínculo afetivo, e dentro dos limites do lar. A sinonimização dos termos, como referentes a um mesmo fenômeno, anula as suas especificidades e limites, ao tempo em que institui, sob um mesmo rótulo, noções diversificadas. 0 próprio termo "violência contra a mulher" (que já determina a vítima, ao revés dos demais que podem ter como vítimas homens ou mulheres) diz respeito a qualquer tipo de violência (física, sexual, psicológica) cometida dentro ou fora de relacionamentos, por pessoas conhecidas ou não. Esta violência pode ocorrer no trabalho, na igreja ou na escola. Contudo, mesmo tratando-se de termos passionais e eivados de confusões terminológicas, é evidente o impacto político alcançado por estas categorias (IZUMINO, 2004).

A idéia de "cumplicidade" feminina, rejeitada em 1980, foi retomada nos anos 90, quando os debates passaram a questionar o papel das mulheres dentro das relações violentas. A desconstrução da noção de "vitimização" foi desenvolvida pelo trabalho de Maria Filomena Gregori (1993) intitulado "Cenas e queixas: um estudo sobre as mulheres, relações violentas e práticas feministas". A teoria 
de Gregori é que violência conjugal pode ser entendida como uma forma de comunicação do casal, na qual homens e mulheres conferem significados as suas práticas e aos seus papéis sociais de gênero. Evidenciando o fato de que a mulher também pode desempenhar o papel do sujeito ativo nas relações violentas, sai de cena a "vitimização" substituída pela relação de "cumplicidade comunicacional": as mulheres são cúmplices de seus parceiros ao estabelecer esta comunicação na busca de significados para os papéis de gênero. Isto desloca o foco da análise das desigualdades de poder entre homens e mulheres para a noção de que a violência conjugal é fruto de um jogo relacional entre o casal.

0 retorno da idéia de alocar as mulheres como 'cúmplices' gerou desconforto e críticas de feministas e acadêmicas. Mas, a possibilidade de relativizar o papel da mulher na relação violenta inaugura um novo debate acerca do tema a partir de 1990. À visão estruturalista dos anos 80, na qual as mulheres são condicionadas à subordinação e passividade, sendo a violência algo permanente e imutável dentro da sociedade, foi contraposta a teoria de Gregori que vê as mulheres como sujeitos, com capacidade de agir, num campo limitado de possibilidades, mas com recursos e mecanismos de ação e transformação. A "vítima" é substituída pelo entendimento do processo de construção de significados intercambiáveis e flexíveis capazes e alocarem os atores envolvidos em posições que se alternam e se modificam, dependendo de quem interage com eles (ROMEIR0, 2006).

A pesquisa de Gregori (1993), ainda, evidencia o fato de que esta manipulação da condição de "vítima" perante as autoridades é a conclusão do processo de diálogo entre o casal que antecede a cena de violência, onde a mulher tenta exercer a autoridade que não dispõe perante o marido, na busca em dar a "última palavra".os relacionamentos violentos tornam-se um jogo onde não existe, nos atos de comunicação, um acordo, entendimento ou negociação das decisões. Os parceiros se lançam neste jogo por motivos diversos: em busca de prazer, produzir vítimas ou culpados ou, ainda, recompor as imagens e condutas do masculino e do feminino. Quando as mulheres são subjugadas, buscam o apoio externo e no procedimento de "queixar-se" reconstroem os fatos evidenciando a sua condição virtuosa e a culpabilidade do outro. Angariar o apoio externo cumpre a função de restabelecer o equilíbrio da relação no conflito, quando as mulheres não se sentem portadoras de autoridade diante de seus maridos.

Esta nova abordagem dos anos 90 é responsável pela mudança na perspectiva teórica: relativiza-se a relação vítima/agressor, questiona-se as categorias feminino/masculino, introduz-se o conceito de gênero nos debates 
acadêmicos sobre a situação da mulher e emerge-se a noção de "violência de gênero", ao invés de "violência contra a mulher".

0 sentido de gênero nos novos debates está vinculado ao trabalho de Joan Scott (1989), Gênero: uma categoria útil de análise histórica, ao invés do patriarcalismo como sistema estruturante do fenômeno da desigualdade entre homens e mulheres, propõe-se que gênero deve ser entendido como um campo primário onde, ou por onde, o poder é articulado - as relações sociais baseiam-se nas diferenças entre os sexos e se organizam pela lógica desigual do poder entre homens e mulheres. Em outras palavras, não seria o patriarcalismo que institui a diferença e a hierarquia dos sexos, mas as diferenças estabelecem uma divisão desigual de poder entre homens e mulheres que institui o patriarcalismo.

A lógica das relações sociais galgadas nas diferenças sexuais, para Scott, são mantidas por quatro dimensões interrelacionadas: a dimensão simbólica, a normativa, a organizacional e a subjetiva. Na dimensão simbólica, constroemse os papéis através de representações simbólicas dos gêneros. A dominação ou apropriação social de determinados mitos simbólicos, norteiam a apropriação dos papéis por homem e mulher. A interpretação dos símbolos seria feita pela dimensão normativa, pela disseminação dos conceitos religiosos, educativos, científicos e políticos; a própria eleição dos símbolos a serem instituídos é competência desta dimensão que realiza através das instituições, agora jána dimensão organizacional. As instituições, produtos da dimensão normativa, agem no sentido de aprofundar a hierarquia entre os gêneros.

Na dimensão subjetiva, cabe analisar a forma de construção daidentidade de gênero e como se relacionam com as instituições sociais e representações culturais situadas historicamente. Gênero é, pois, uma categoria relacional e histórica, produto de construção social. Os sujeitos devem ser analisados do ponto de vista de sua complexidade e não de uma perspectiva dual, comparativa. Universalidades sobre 0 antagonismo entre homens e mulheres não servem a conceito de gênero, que precisa analisar homens e mulheres em contextos históricos determinados. As peculiaridades de cada momento histórico, no âmbito das três primeiras dimensões, conduzem a formação da quarta dimensão subjetiva de maneira singular.

Dentro da perspectiva de gênero de Scott (1989), as mulheres devem ser pesquisadas do ponto de vista das relações que estabelecem com as estruturas sociais em que estão contidas, e não dentro de uma categoria universal e impessoalmente admitida, como categoria "vítima" ou mesmo "cúmplice". 
Saindo de trabalhos com caráter marcadamente de denúncia e militância, que prejudicavam a neutralidade científica, os teóricos dos anos 90 adotam uma mudança de foco nos estudos sobre a violência de gênero, o que faz deslocar a atenção dos registros de ocorrência e do perfil vítima/agressor, para as dinâmicas dos atores e os procedimentos das instituições especializadas. A violência contra a mulher passou a ser vista além da divisão sexual do trabalho patriarcal e da dominação masculina.

A rápida absorção do conceito de gênero, no Brasil, se dá porque esta categoria neutraliza o caráter político dos estudos sobre a mulher, o que possibilitaria a desvinculação política que envolvia as pesquisas acadêmicas e 0 discurso do movimento feminista. Neste compasso, conceitos como "violência contra a mulher", "violência doméstica", "violência familiar", no âmbito acadêmico, foram substituídos por "violência de gênero" que confere ao fenômeno violência o significado do resultado de construções sociais dos papéis masculinos e femininos a partir de relações desiguais de poder multidimensionadas (ROMEIRO, 2006). Introduz-se, aqui, a noção de poder no tema violência doméstica/ familiar, constituindo-se a oportunidade de estender as discussões políticas, com a possibilidade de visualizar a mulher como sujeito ativo e dono do poder de transformação e não a simples vítima que se originou dos ecos do feminismo clássico.

Todavia, a apropriação da categoria "violência de gênero" pelo discurso militante do movimento feminista resultou na sinonimização com "violência contra a mulher" novamente, o que já havia sido superado nas análises acadêmicas (IZUMINO, 2004). Mais uma vez, a despeito do esforço da produção acadêmica em universalizar e neutralizar o estudo e o foco da atenção para a questão da violência, a apropriação do discurso acadêmico pelo senso comum da militância, acabou por reduzir o seu limite de abrangência e compreensão. 0 questionamento que a ciência social impôs aos seus paradigmas não foram, destarte, absorvidos pela militância com a mesma completude e significância.

Essa confusão das categorias, promovida pelo não assimilamento dos atuais questionamentos acadêmicos sobre o tema, resultou na evidente dificuldade de conceituar os termos, redundando na indefinição do objeto sobre o qual se pleiteia a intervenção, no âmbito da relação entre o movimento político e as instituições. Esta dificuldade teórica e conceitual implica diretamente nas dificuldades enfrentadas por estas instituições no sentido de erradicar a violência, por não lhe oferecer definições claras sobre as múltiplas dimensões do tema. 
Os reflexos desta cisão entre o desenvolvimento e reflexão do tema violência conjugal entre a pesquisa científica e o movimento político reverberam nos discursos produzidos no nível das instituições que, ao adotarem a posição mais radical e categorizante do primeiro momento do trabalho do feminismo acadêmico, acabou por produzir políticas públicas muitas vezes dissonantes dos múltiplos aspectos da realidade social que pretende transformar.

\section{AÇões AFIRMATIVAS ESTATAIS, DIREITO E DEMOCRACIA}

Para que a Constituição cumpra a sua função e não sirva de substrato para qualquer tipo de arbítrio, é inexorável que ocorra uma opção paradigmática para sua interpretação: deseja-se fundamentar/justificar discursos ou compreendêlos fenomenologicamente, em outras palavras, pretende-se estabelecer verdades absolutas pela norma ou buscar-se o consenso através delas?

É próprio deste constitucionalismo compromissório e dirigente trazer à baila de sua ordem discussões que antes de restringiam somente à esfera privada. A publicização dos espaços privados decorre da assunção de uma materialidade pelas Constituição - como a de 1988, que altera as fontes que sustentavam o positivismo, propiciando uma nova teoria da norma onde atrás de cada regra subsume-se um princípio que não a deixa desvencilhar-se do mundo prático, deixando para trás o esquema sujeito-objeto e exigindo um novo paradigma interpretativo.

Isso significa dizer que, se o modelo de direito sustentado por regras está superado, o discurso exegético-positivista, ainda dominante no plano da dogmática jurídica praticada cotidianamente, representa um retrocesso, porque, de um lado, continua a sustentar discursos objetivistas, identificando texto e sentido de texto (norma), e, de outro busca, nas (diversas) teorias subjetivistas, a partir de uma axiologia que submete o texto à subjetividade assujeitadora do intérprete, transformando o processo interpretativo em uma subsunção dualística do fato à norma, como se fato e direito fossem coisas cindiveis e os textos fossem meros enunciados lingüisticos. (STRECK, 2007, p.8 - com destaque no original).

Neste plano é que ocorre a difusão da filosofia pela linguagem, a exemplo da teorização de Habermas (1997), em uma pós-metafísica que (re) inclui a faticidade que espera superar o esquema sujeito-objeto (que tem caráter instrumental, estratégico, desconsiderando a dimensão comunicacional da racionalidade humana) estabelecendo uma reflexividade profícua da compreensão. 0 déficit de 
realidade do esquema positivista vem a ser preenchido pelas posturas interpretativas "que deixam de hipostasiar o método e o procedimento, colocando no modo-de-ser e na faticidade o lócus da compreensão" (STRECK, 2007, p. 9) - assim partiremos do fundamentar para o compreender, sendo esta compreensão não mais um agir do sujeito, mas um modo de ser dentro de uma intersubjetividade. Entretanto, ainda vivemos uma realidade jurídico-normativa cuja metodologia tem a função de desvincular o caráter historicamente individualizado do caso que lhe seja a base, para atingir o abstrato generalizável e comum.

A partir destas considerações, é possível estabelecer uma observação mais aclarada da metodologia positivista aplicada a lei infraconstitucional editada para cuidar da faticidade da violência nas relações de gênero, no Brasil. 0 modelo sujeitoobjeto (agir estratégico) de direito aplicado na ação legislativa que redundou na criação da lei, nos passos de uma metodologia positivista, hipostasiou o método e o procedimento, desvinculou o caráter historicamente individualizado do fato e privilegiou o mais alto grau de abstração generalizável e comum para normatizar a questão, assumindo uma postura ordenadora.

É importante destacar também que a partir do momento em que a violência contra a mulher se torna um campo de intervenção e normatização, a violência como um processo dinâmico das interações sociais entre os atores e de como cada um contribui e participa da interação violenta deixa de ser o foco da atenção na medida em que a dualidade vítima e agressor são as únicas consideradas como estruturantes da relação violenta (ROMEIRO, 2007, p.38).

Dos filósofos modernos que cuidam de direitos fundamentais e democracia face à Constituição e os papéis do Estado, Habermas (1997) dá primazia ao processo político de formação da vontade livre de distorções, sem relegar a defesa dos direitos fundamentais - mas este é o segundo plano de sua teorização. Ele defende que as desigualdades impostas pela sociedade capitalista devem ser compensadas mediante a distribuição justa dos bens coletivos - e eis que reside nisto uma obrigação do Estado, paradigma já incorporado na modernidade.

Esta posição é compatível com a tese de que os direitos sociais fundamentais são uma parte do sistema de direito moderno, contudo, o conteúdo de tais direitos deve ser fixado mediante a autodeterminação política dos cidadãos no processo democrático, pois somente pode haver tais direitos se eles forem legais, e a legalidade está (na conformação do Estado Constitucional da democracia participativa) estreitamente ligada com a legitimidade que se obtém pelo processo democrático de 
eleição dos preceitos que regerão esta mesma sociedade de cidadãos. Distribuição de direitos e democracia já são princípios incorporados pelos modernos, então qual onde reside a dificuldade de atualizar o conceito de igualdade?

Referindo-se às duas dimensões da sociedade, na teoria de Habermas, temos: o mundo-da-vida, sociedade civil - espaço onde o processo comunicativo se dá, onde as relações intersubjetivas se organizam intuitivamente, onde ocorrem as problematizações e discussões práticas que conduzem as discussões de valores morais ; e o mundo sistêmico - espaço caracterizado pelas organizações estratégicas, econômicas e políticas, onde impera a não linguagem, a não discussão, a macroestrutura na qual se organizam as formas de produção do capitalismo mecânico e instrumental que comanda o mundo simbólico da vida.

Outro ponto destacado de sua teoria é que a racionalidade é uma dimensão intrínseca à modernidade e que, diferente de teorias clássicas a respeito da ação racional, ela deve ser analisada em suas mais amplas dimensões. Essas dimensões, dizem respeito, por um lado, à busca da subsistência que orienta a relação dos homens com o mundo dos objetos e, por outro, a busca do entendimento que orienta à relação dos homens entre si. Na relação com os objetos, os homens buscam um resultado, portanto são orientados por uma racionalidade estratégica; nas relações interpessoais, buscam o entendimento, daí a orientação pela racionalidade comunicativa. Mas acrescente-se a esta análise um caso excepcional de relações interpessoais em que o indivíduo funciona como meio para o outro alcançar um resultado, muito embora seja uma relação interpessoal como a comunicativa, não havendo interesse em entendimento e sim em resultado, terá um caráter instrumental. A idéia de sujeito-sujeito, que regulam as ações comunicativas por normas de convivência, é substituída pela idéia de sujeito-objeto, pois um deles figura como objeto para o outro na busca dos objetivos, que se regulará por regras de eficácia.

Analisar a racionalidade nestes desdobramentos, para Habermas, tem 0 objetivo de romper os estritos limites que uma compreensão estreita ou unilateral desta racionalidade impõe ao pensamento social. Sem pretender exaurir os meandros dos constitutivos da teoria da ação, é importante fixar que a idéia básica é que toda interação social implica um uso específico da linguagem e isto se aplica tanto à ação estratégica quanto à ação comunicativa. A especificidade da ação comunicativa está atrelada a seu objetivo: o entendimento entre os parceiros da interação. Toda racionalidade comunicativa implica numa dimensão reflexiva da 
ação, em que as reivindicações de validade das posições assumidas conduzem a um consenso racional, fundado nas razões que resistiram ao exame da interação racional dos indivíduos. Racionalidade, assim, é um processo, algo em ato, não um atributo de alguma coisa dada (COHN apud CARVALHO, 1993).

A racionalidade, oriunda deste agir comunicativo, que se contrapõe à colonização imputada pelo sistema político e econômico (relação sujeito-objeto, com vistas ao resultado no agir estratégico), poderia transformar-se numa crítica esclarecedora e conduzir à emancipação dos indivíduos do jugo desta racionalidade estratégica que é imputada pelo mundo sistêmico e cuja ferramenta primordial é o direito que cristaliza, na norma positivada, as verdades que se transmudam em enunciados ordenadores do Estado. 0 direito produzido sem considerar a dimensão comunicativa da racionalidade traduz-se num atributo de alguma coisa dada, numa verdade pré-estabelecida e não num processo, algo em ato, fundado em razões que resistiram ao exame da interação racional dos indivíduos.

Os indivíduos poderão se descolonizar somente à medida que forem livres para analisar, discutir e problematizar. Mundo-da-vida e agir comunicativo são conceitos que se integram, pois a ação lingüística é imanente àquele, da mesma maneira que o Mundo do Sistema coexiste ao agir instrumental. 0 desgaste entre esses mundos é permanente, pois, ora as estruturas sistêmicas organizam e estruturam o mundo-da-vida, colonizando-0; ora, o mundo-da-vida se manifesta contra a instrumentalização de coação social imposta pelo mundo sistêmico. A racionalidade comunicativa, dimensão própria da modernidade, empurra os indivíduos contra a racionalidade estratégica do mundo sistêmico. 0 consenso é algo possível, mas não necessariamente realizado em todas as ocasiões empíricas; ao contrário disto, em determinadas circunstâncias este consenso não tem como se realizar e é substituído pela incorporação, no interior do processo de comunicação, de coerções relativas ao mundo sistêmico, substituindo o entendimento mútuo pela obediência, que é o oposto da ação comunicativa.

Entretanto, a racionalidade comunicativa, isoladamente, não tem força suficiente para impor as pretendidas relações de entendimento e solidariedade, própriado mundo-da-vida, sobre o mundo dossistemas. Estaforma de comunicação própria do mundo da vida não encontra tradução na racionalidade estratégica da economia e da política, acostumadas à linguagem formal. Acresça-se a isto, o fato de que a complexificação da sociedade moderna resulta na colonização do mundo-da-vida pelos sistemas sociais, à medida que a economia e a política 
passam a reger cada dia mais o cotidiano das pessoas, implicando na redução significativa da racionalidade comunicativa e sua gradual substituição pela racionalidade estratégica.

À vista disto, o direito, como dissemos, surge como o sistema social que se vale da racionalidade estratégica com a finalidade de estabilizar as expectativas de comportamento, com o emprego de uma racionalidade processual formal, que gera confiança nos cidadãos na dominação legal, invadindo o mundo da vida, aumentando a juridificação das relações sociais e fomentando a retração do agente para a sua esfera privada (DURÃO, 2006). 0 direito e as leis produzidas dentro desta realidade social servem como instrumento legítimo de colonização, de ordenação, pois conseguem angariar a confiança da sociedade civil em sua eficácia para solver os conflitos. Os indivíduos, cada vez mais retraídos aos espaços privados, substituem a fé das sociedades tradicionais, pela crença na lei. E o legislador deve ter, neste contexto, a árdua tarefa de prever a exaustão, todas as possibilidades fatuais dos dissensos do mundo-da-vida para contê-los nos enunciados normativos; a lacuna, que obviamente se instaurará em algum momento, transfere a responsabilidade da solução dos conflitos sociais para 0 poder hermenêutico dos juízes - o decisionismo e a discricionariedade darão a fundamentação, subsumindo o fato à norma - a realidade social a adequar-se à verdade pré-estabelecida.

Na visão habermasiana da democracia, a possibilidade de integração social ${ }^{4}$, na sociedade contemporânea, decorre da reconstrução do papel desempenhado pelo sistema jurídico: a reconstrução racional da filosofia política e do direito e do próprio conceito de direito. Nesta teoria, o direito torna-se responsável pela integração dos mundos, por conter em si a possibilidade do uso das duas racionalidades: a) uso da racionalidade estratégica - no momento em que 0 indivíduo obedece a lei por medo da coerção, ao racionalizar sobre as vantagens em descumprir a lei e arcar com o ônus advindo das sanções nela previstas; b) uso da racionalidade comunicativa - quando os cidadãos agem conforme a lei, por estar convencidos de sua legitimidade - legitimidade cujo conceito se integra com a participação democrática na compreensão e fundamentação do fato social

Os modernos, segundo ele, devem ser livres para discutir a validade dos discursos provenientes tanto do mundo das ciências e da política (com suas

\footnotetext{
${ }^{4}$ A integração social é aquela promovida pelas relações de solidariedade, resultante do entendimento recíproco dos indivíduos do mundo-da-vida.
} 
verdades factuais) quanto do mundo da moral (com suas regras e normas sociais, próprias de cada grupo social). A razão válida deve conferir capacidade para relativizar as "verdades" e poder assumir sua posição diante do que considera "verdade" dentro de um contexto democrático de discussão dialógica - este é o seu movimento filosófico que vai da fundamentação para a compreensão, da verdade para o consenso, como proposta para superar o problema do decisionismo e da discricionariedade do positivismo. Num Estado que tem o papel, ainda que secundário, de fomentar e promover a distribuição justa dos bens coletivos, os movimentos sociais se constituem a gênese da razão comunicativa, expressão coletiva da insatisfação dos povos com as políticas estratégicas do sistema políticoeconômico dos países, tanto do primeiro mundo, como os de terceiro mundo (HABERMAS, 1997).

0 grande entrave à efetivação do princípio da isonomia estaria, então, na própria possibilidade de diálogo entre mundo-da-vida e mundo sistêmico: os movimentos sociais (que são categorias organizadas, minorias ativas, como dissemos) são quem expressam a insatisfação social com as estratégias políticas do mundo sistêmico, são a própria expressão do agir comunicativo democrático tratado por Habermas, mas o fazem segundo as diretrizes do paradigma que pretende ordenar estas estratégias. A fundamentação do discurso no agir comunicativo destas categorias não parte para uma compreensão universal dos direitos socialmente considerados, mas para um decisionismo sobre qual posição aprioristicamente estabelecida deve prevalecer. 0 princípio da isonomia estaria garantido à medida houvesse uma distribuição igualitária de oportunidades de intervenção na interação comunicativa dos participantes - sejam grupos organizados, ou cidadãos.

Por conter as duas possibilidades de racionalidade, o direito deveria ser o transformador lingüístico que possibilitasse a comunicação entre o mundoda-vida e o mundo sistêmico, traduzindo a linguagem formal de um para a linguagem comunicativa do outro e vice-versa. Construindo-se a ciência jurídica privilegiando-se espaços públicos de discussão legítima - ou, em outras palavras, estabelecendo-se um a priori da norma posta, possibilita-se que reivindicações do mundo-da-vida possam transformar-se em leis que afetam os sistemas sociais de modo que conduzam a sua racionalidade estratégica para que as ações por eles implementadas no mundo-da-vida, sejam vistas como válidas.

Esse movimento reflexivo imposto pelo modelo da ação comunicativa validaria as ações do Estado porquanto elaboradas democraticamente com a 
efetiva participação dos cidadãos, através do debate livre nos espaços públicos. As leis, assim, desnecessitariam cada vez mais de sua coercitividade para serem cumpridas e o processo de colonização, com o uso legítimo da força pelo Estado, seria paulatinamente substituído pela convivência harmoniosa baseada no consenso. Para Habermas, a única coerção legítima à ação, em princípio, é a racionalidade - é ela que funda e confere legitimidade a todos os demais procedimentos reguladores da ação, como as normas (COHN apud CARVALHO, 1993).

0 mundo-da-vida não poderia ser mero receptor de estratégias, (porque a função ordenadora do direito é própria de uma racionalidade que não encontra correspondência na modernidade), mas deve participar ativamente na elaboração das políticas sistêmica da qual é receptor. Como forma de garantir a democracia, não pode haver o desequilíbrio entre direito e política, e o poder político deve basear-se nos princípios de uma Constituição que seja construída por um processo democrático. Tais princípios teriam a legitimidade de autorizar o Estado a pacificar os conflitos sociais, a partir de sua própria interpretação, e este movimento entre mundo sistêmico (Estado) em relação ao mundo-da-vida (sociedade civil), não estaria condenado ao decisionismo e à desindexação do mundo prático do discurso jurídico.

Do ponto de vista normativo, o processo de circulação do poder legitimamente produzido no estado democrático de direito deve permitir que o poder comunicativo dos cidadãos possa se transformar no poder administrativo empregado pelas instituições públicas e neutralizar o poder social dos interesses particulares (HABERMAS apud DURÃ0, 2006, p.117).

Contudo, apesar de contribuição da construção teórica habermasiana para superar as diversas formas assumidas pelo positivismo jurídico, mesmo dentro de modelos de Estado democráticos, e resolver os problemas da impossibilidade de antever todas as possibilidades de utilização e aplicação da norma positivada, Habermas acaba por incorrer na própria problemática que pretendia criticar no positivismo, ao apostar na construção de discursos prévios de justificação/ fundamentação da validade normativa, ao elaborar a teoria discursiva e pretender estabelecer as condições ideais de fala em um panorama democrático, na busca do consenso. De alguma forma, trata-se de "aprisionar" a realidade (outrora subsumida na norma) por intermédio de nossa rede de sentidos, o que Streck (2007) apelidou de filosofia da consciência. Habermas acabou apenas por deslocar o problema da atribuição do sentido para uma contrafática situação ideal de fala 
que, para superar a tensão entre fato e norma, acabou por servir de justificação prévia ao procedimento de adequação entre a faticidade e a validade.

Desvendar o positivismo e sua discricionariedade, não nos livrou da impossibilidade de fazer coincidir os discursos de validade e os discursos de adequação, ou seja, fazer coincidir o texto e o sentido do texto, e nos deparamos com os problemas de leis que não encontram ecos na realidade social que pretende transformar estrategicamente, pela adoção de um sentido apriorístico de ideais de justiça ou de igualdade.

É preciso fixar que é difícil sustentar teses procedimentais como a de Habermas, frente a países de modernidade tardia como o Brasil, em que parte dos direitos fundamentais da sociedade continua sem cumprimento. É pretensioso conferir ao PoderJudiciário a única função de "zelar pelo respeito aos procedimentos democráticos para a formação de opinião e vontade política, a partir da própria cidadania" (STRECK, 2007, p.26), como apregoa a teoria de Habermas. Ele critica a invasão da política e da sociedade pelo direito, mas há que se considerar que 0 direito, no palco sociológico é apenas uma variável das disputas e, portanto, não podemos modificar e nem explicar a realidade social somente por ele, como se as teorias jusfilosóficas ou as produções legislativas fossem capazes de condensar toda a dinâmica das interações entre o mundo-da-vida e o mundo sistêmico, num processo de condicionamento reflexivo.

Há, ainda, uma inexorável necessidade do Estado brasileiro em corrigir as desigualdades sociais pela justa distribuição de direitos. Mas poderemos que esta necessidade não pode resvalar em decisões ordenadoras, estratégicas, do Estado, que pretende, (como dissemos), traduzir a realidade social dinâmica, instável e composta de variantes objetivas e subjetivas diversas, em leis que cristalizam categorias e estabelecem a priori como fundamentos de uma suposta transformação da realidade, que passa a depender das boas intenções interpretativas de seus aplicadores.

Não se pode olvidar, entretanto, do fato de que a Lei 11.340/06 tenha sido concebida a partir de interações entre mundo-da-vida e mundo-sistêmico, ainda que pelas expressões políticas de movimentos sociais organizados. A ação do Estado foi em resposta a diversas e históricas discussões sobre a desigualdade de gênero, cujo objetivo estratégico é minorar tais desigualdades, mas numa estratégia desenvolvida a partir de uma interação comunicativa entre as instâncias políticas da sociedade e as instituições estatais. Todavia, a guisa de tantas intervenções do 
Estado no sentido de proteger a mulher da violência doméstica, de tantas discussões políticas sobre o tema, de tantas reivindicações, esbarramos num tema que nos intriga - por que verificamos o fenômeno da permanência de mulheres em relações violentas, inclusive opondo-se ou desconsiderando o protecionismo estatal inscrito na lei? Será que o sentido de isonomia de direitos entre homens e mulheres vindicados pelo movimento que entabulou a Lei 11.340/06 encontra respaldo no sentido de isonomia de cada membro da sociedade considerado individualmente? Seria legítimo universalizar o consenso de uma categoria, portanto?

É preciso considerar a desnecessidade da produção legislativa infraconstitucional para garantir direitos fundamentais para as mulheres (já que no caso da lei em comento a problemática da violência doméstica restringiu-se àquela direcionada somente às mulheres, olvidando da possibilidade do homem também ser vítima), já previstos na ordem constitucional vigente em diversos artigos que expressam os princípios ordenadores do Estado.

A promulgação da Constituição de 1988 já garantiu tanto às mulheres quanto aos homens os direitos fundamentais e à proteção contra qualquer tipo de violência, sendo o Estado o responsável pela sua efetivação. Por expressa disposição constitucional, as normas definidoras de direitos e garantias tem aplicabilidade imediata (artigo $5^{\circ}$, parágrafo $1^{\circ}$ ), ou seja, prescinde de qualquer produção legislativa posterior para ter efetividade. A dignidade da pessoa humana é um princípio do nosso Estado Democrático, como também a ausência de discriminação de gênero, a igualdade de homens e mulheres em direitos e obrigações. Por fim, cuidando especificamente da violência no âmbito doméstico, apregoa a Carta Constitucional de 1988:

Art. 226. A família, base da sociedade, tem especial proteção do Estado.

$\S 8^{\circ}$ - 0 Estado assegurará a assistência à família na pessoa de cada um dos que a integram, criando mecanismos para coibir a violência no âmbito de suas relações.

Os mecanismos referidos no artigo constitucional são ações materiais específicas no sentido de dar efetividade a norma constitucional, dentro da leitura universal de seus princípios. A Lei 11.340/06, ao prescindir da universalidade destes princípios constitucionais e legislar especificamente para o fato social "violência contra a mulher", adotou uma postura ordenadora, individualista e decisionista, ao fixar num fato social complexo categorias eleitas à priori - partiu da fundamentação para a compreensão, subsumiu o fato à norma, atendeu a apenas uma vertente do debate que envolve a questão. 


\section{CONSIDERAÇõES FINAIS}

Combater a violência e a desigualdade de gênero é uma função do Estado, nisso todos concordam. 0 problema está em como conferir efetividade a uma lei generalizante que atende aos pressupostos de um movimento político, sem conseguir, no entanto, universalizar a ação ali inscrita para os principais destinatários da lei.

Refletindo sobre as questões que levantamos acima, sobre a universalidade do sentimento de discriminação na relação conjugal, Gregori (1992) a partir de uma pesquisa de campo numa instituição de assistência à mulher em situação de violência, considerou que as ações que se definem por meio de uma ajuda ao cliente/demandante (como o são as mulheres, perante a sistemática da Lei Maria da Penha) devem, para além do assistencialismo, despertar a ação política destes sujeitos e contribuir para constituí-lo como sujeito político defensor de seus direitos.

$\mathrm{Na}$ elaboração da lei, houve uma preocupação excessiva com 0 assistencialismo a ser promovido pelo Estado - tratar os desiguais igualmente, na medida de sua desigualdade, não importa, em dar novo significado à desigualdade de gênero, mas tão somente proteger os que identificamos em situação de desigualdade. Não há uma contribuição peculiar para despertar as mulheres aqui nos reportamos universalmente a todas as cidadãs que se encontram dentro e fora de movimentos políícos - para o fato de que ela é discriminada e para que lute pelo reconhecimento de seus direitos, não somente perante o Estado, mas no questionamento dos papéis e valores que imprimem as suas relações.

0 assistencialismo resvala na ineficácia de resolver definitivamente 0 problema à medida que não questiona crenças e valores que sustentam posturas tradicionais para o homem e para a mulher. Paternalismos legais contribuem para asseverar a condição de não sujeito, para potencializar a incapacidade de tornar-se o titular do próprio direito. 0 processo emancipatório só é efetivo se criar condições para que as mulheres descubram juntas e em grupo como viver segundo um novo código de comportamento. Enquanto isto não acontece, as mulheres, destinatárias da norma, encontram dificuldades no processo de ressignificação de seus papéis.

As mulheres convivem entre si e nem sempre percebem que são oprimidas. Há um processo evidente de interiorização da dominação sofrida pelas mulheres, que não parece ser descomposto por políticas assistencialistas. Desta forma, idéias como casamento, o desejo de um homem em casa, ter um pai para o filho, a 
exclusividade sexual ou a necessidade de companhia continuam tendo grande importância na manutenção de situações que o Estado pretende, com uma ação coercitiva, resolver.

0 trabalho de conscientização que o movimento das mulheres, politicamente organizadas e num diálogo com as instituições, pretendeu aplicar com a instituição da lei tenta produzir a experiência de igualdade mediante da criação de uma identidade abrangente. 0 esforço de unificar as mulheres em torno da denúncia da opressão masculina encontra apoio na experiência imediata: a mobilização é feita nas instituições de proteção às mulheres vítimas de violência, onde o problema afeta a todas que ali se dirigem. 0 mundo dos homens e o mundo das mulheres é uma divisão que todos conhecem. Porém, sabemos que o mundo das mulheres não é homogêneo. 0 entendimento sobre papéis, direitos e opressão se diferencia e existem conflitos que emergem nesse processo de diferenciação. E, se assim não fosse, não teríamos o fenômeno observado do retorno de mulheres às situações violentas ou mesmo a opção por não denunciar o agressor.

0 movimento feminista separa mulheres dos homens não tanto no sentido de afirmar que cada homem é responsável pela opressão, mas na medida em que todo o trabalho de conscientização é travado apenas pelas mulheres. Cabe aos homens - vistos como coletividade - serem cobrados e denunciados em suas manifestações autoritárias e/ou violentas. A eles não é dada a alternativa de conversão. 0 resultado disso é que a adesão das mulheres não é facilmente garantida, já que elas estabelecem relações de afinidade e intimidade com os homens, e, sem dúvida, encontram benefícios (afetivos, sexuais, de estabilidade social e, muitas vezes, econômica) nessas relações (GREGORI, 1992, p.54).

As ações afirmativas encontram enormes dificuldades em compreender as diversas circunstâncias que envolvem a vida das mulheres. Isto pode ser atribuído ao u projeto político que pretende aglutinar todas as mulheres em função de uma característica muito abrangente e pouco singular - a opressão.

Em lugar de examinar a verdadeira composição social do nosso movimento e as forças e experiências que tornaram radicais alguns grupos de mulheres, o feminismo do movimento de libertação das mulheres pode ser apresentado como a consciência das mulheres em geral. Isto torna impossível resolver a relação do movimento com as mulheres que ainda não se envolveram com ele. Sua ausência tem sido de fato justificada e negligenciada. (...) As feministas precisam apenas sondar esse poço de senso comum para alcançar o que toda mulher sabe (ROWBOTHAM apud GREGORI, 1992, p.56). 
Assim, todas as vezes que a atuação estatal confrontar-se com uma resistência feminina chegar-se-á a paradoxal postura de considerar que tais mulheres não the dizem respeito. Diante de mulheres que optam por manteremse em situações de violência, que recusam ou resistem à proteção do Estado, irão se proliferar interpretações sobre a cumplicidade delas com a violência que thes é perpetrada, a idéia de que elas têm compensações. Poder-se-ia questionar: se a lei lhe garante escolhas, porque elas optam pela relação violenta? Não podemos desconsiderar o fato de as mulheres realmente encontrarem satisfação e benefícios afetivos e financeiros em relações conjugais violentas. Mas não podemos subsumir a resposta a uma simples troca, seria maniqueísta considerar desta forma.

Ações afirmativas com esta conotação decisionista, que pretende submeter o fato ao direito, e não considerar a sua complexidade para obter a resposta, desconsideram todos estes aspectos da questão. As mulheres, que a lei pretende proteger da violência masculina, vivem num universo sociocultural no qual todos os valores existentes têm relevância prática. Os valores são importantes para elas e para todos os que as cercam (GREGORI, 1992). Muitas vezes, escolher entre ficar e ir tem custos altos demais, cuja dimensão subjetiva não foi contemplada pela ação assistencialista do Estado - e está além, inclusive, de questões financeiras. Consciências mudam num processo lento, e procedimentos protecionistas, por vezes, fracassam. Os costumes, valores e crenças atrelados ao problema e desconsiderados pelas políticas de proteção feminina só poderão ser modificados a partir de uma perspectiva mais abrangente.

\section{REFERÊNCIAS}

AZEVED0, Maria Amélia. Mulheres Espancadas: a violência denunciada. São Paulo: Cortez, 1985.

BRASIL. Secretaria Especial de Política para as Mulheres - SPM. Plano Nacional de Políticas para as mulheres. Brasília-DF, dez. 2004. Disponível em <http//200. 130. 7/spmu/docs/PNPM.pdf>

. Constituição da República Federativa do Brasil. 1998. São Paulo: Atlas.

Lei 11.340 de 07 de agosto de 2006. Dispõe sobre a criação de mecanismos para coibir a violência doméstica e familiar contra a mulher. 
Disponível em https://www.planalto.gov.br/.

BONAVIDES, Paulo. Teoria do Estado. São Paulo: Malheiros Editores, 2007.

COSTA, Albertina de Oliveira e BRUSCHINI, Cristina. Uma questão de gênero. Rio de Janeiro: Rosa dos Tempos, Fundação Carlos Chagas, 1992.

CARVALHO, Maria do Carmo Brant de (org.). Teorias da ação em debate. São Paulo: Cortez : FAPESP, 1993.

DURÃo, Aylton Barbieri. A tensão entre faticidade e validade no direito segundo Habermas. Revista Ethic@, v.5, n.1, Universidade Estadual de Londrina, 2006, p.103-120.

GREGORI, Maria Filomena. Cenas e queixas: um estudo sobre mulheres, relações violentas e práticas feministas. Rio de Janeiro: Paz e Terra. São Paulo: ANPOCS, 1992.

HABERMAS, Jurgen. Consciência moral e agir comunicativo. Rio de janeiro: Tempo Brasileiro, 1989.

. Direito e Democracia: Entre Validade e Facticidade. Rio de Janeiro: Tempo Brasileiro, 1997. Vols. 1 e 2.

IZUMINO, Wânia Passinato. Violência contra a mulher no Brasil: acesso à Justiça e a construção da cidadania de Gênero. Trabalho apresentado no VII Congresso Luso-Afro-Brasileiro de Ciências Sociais, Coimbra, 2004. Disponível em http:// www.ces.uc.pt/lab2004/inscricao/pdfs/painel112/WaniaPasinatoIzumino.pdf.

MACHADO, Lia Zanotta. Violência Conjugal: os espelhos e as marcas. Série Antropologia. Brasília, 1998.

PEDRO, Joana Maria e GROSSI, Miriam Pillar. Masculino, Feminino, Plural. Gênero na Interdisciplinaridade. Florianópolis: Editora Mulheres, 1998.

PERON, Ana Paula. Entre relatos e registros: a discursivização da violência conjugal na delegacia da mulher em Maringá. Dissertação (Mestrado em Letras). Universidade Estadual de Maringá-PR, 2007.

PINKER, Steven. Tábula Rasa: a negação contemporânea da natureza humana. São Paulo: Companhia das Letras, 2004.

ROMEIR0, Julieta Ferreira. A institucionalização das políticas de combate à 'violência conjugal' no Brasil: inovações e controvérsias. Dissertação (Mestrado em Sociologia e Antropologia) - Instituto de Filosofia e Ciências Sociais - 
Universidade Federal do Rio de Janeiro, 2007.

SAFFIOTI, Heleieth. Rearticylando gênero e classe social. In: COSTA, Albertina de Oliveira e BRUSCHINI, Cristina. Uma questão de gênero. Rio de Janeiro: Rosa dos Tempos, Fundação Carlos Chagas, 1992.

SCOTT, Joan W. Gender: A Useful Category of Historical Analysis. The American Historical Review. Vol, 91. n. 5, Dec de 1986, pp. 1053-1075.

SILVA, Sérgio Luís P. Razão Instrumental e Razão Comunicativa: um ensaio sobre duas sociologias da racionalidade. Cadernos de Pesquisa Interdisciplinar em Ciências Humanas, n.18. Teorias Contemporâneas sobre a modernidade. Universidade Federal de Santa Catarina, 2001.

STRECK, Lenio Luiz. Verdade e Consenso. Constituição, Hermenêutica e Teorias Discursivas, da possibilidade à necessidade das respostas corretas em Direito. Rio de janeiro: Lumem Juris, 2007. 